\title{
EXPERIMENTAL STUDY ON THE SIGNIFICANCE OF THE VARIOUS HEAD POSITIONS IN THE PHONETIC PATHOLOGY
}

\author{
By \\ Y. TORIYAMA
From the Section of Speech and Voice Therapy, Department of Oto-Rhino-Laryngology, Faculty of Medicine, University of Tokyo. (Director: Prof. Dr. I. Kirikae)

In the previous paper, author reported that the various head position such as the head turned or bent to one side will have great influence upon the mechanisum of phonation.

Animal experiments were performed to verify the deformation of the larynx while the head is turned or bent to either side of the neck.

The young dogs in the age from 3 to 6 month were used to the experiment. Their heads wera fixed with plaster of Paris in the position turned and inclined to the left. After a certain period of time in these positions, larynx were removed under general anesthesia.

The following new facts were observed.

In the turned position of the head to one side, the horizontal level of the edge of the vocal cord on the turned side glided from up to down, and in the opposite side the horizontal level moved downwards, and the mucous membrane of the vocal cord glided from down to up.

In the inclined position of the head, the horizontal level dropped down, and rose up in the opposite side. The mucous membrane of edge of vocal cord glided from up to down on the incliined side and in the opposite side from up to down.

The above stated facts obtained, from the animal experiment agreed fairly with those observed n the human larynx of clinical cases.

\section{音声病理学よりみた頭位の意義に関する実験的研究}

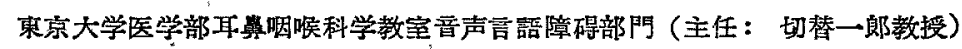

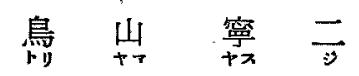

目次

\begin{tabular}{|c|c|}
\hline I 綃 & 論 \\
\hline II 実 & 嗝 \\
\hline 1 & 予借実験 \\
\hline 2 & 実 験 \\
\hline 3 & \\
\hline
\end{tabular}

A 左趈枟頭位

B 左傾斜頭位

III 総括及び考案

IV 結 語

\section{I 緒 論}

音声障碍の原因として，喉頭の左右非対称が重要な役
割をるつのではないかといらことは，早くから気付かれ ていた．喉頭の形態的不均整の音声に及ぼす影響につい ては，声楽における経験的な顴察に止るか，むたは一側 声帯麻痖の場合の変化以外には殆んどこれを知ることは できなかつた。

著者はたまたま片側性声帯炎で形態的に，あるいは機 能的に不均整のある院頭をるつ患者を見出し，ますます その感を梁くした。それは頭位の左右廻転によって生ず る喘頭の形態的不均整が本質的病因となつたと考えられ

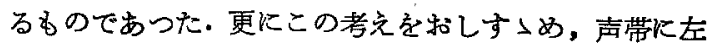
右不均整な病変のある多数の症例について観察し、頭位 の変換が音声に及ぼす影響と，頭部の左右廻転が，搌 
頭・声帯にひきおこす形態的変化について報告した.

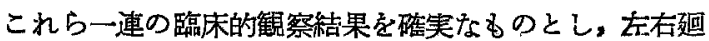
転頭位むるい性左右傾斜（屈曲）頭位儿より咲頭におこ る左右不均整を証明し，頭位の变換が脆頭に及ぼす影響 を詳細に検討する目的をるつて動物実験を行つたのでこ \に報告する。

\section{II. 実験}

\section{1. 予備実験}

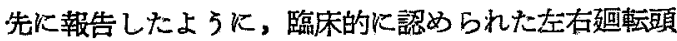
位に抢ける堠頭殊に声帯の变化一一迴檕側では声带辺緑 粘膜の下方より上方への摺動及び辺縁水平位の挙上. 反 対側では声帯辺緑の上方より下方への臎動と，水平位の 低下一が人間と同様に実験動物でる認められるかる知 るために次の予備実験を行った。

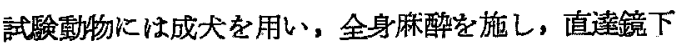
に声帯を直視しつ〉，左右廻転頭位に動かし觀察した。 その際観察に便なるように，在声带辺縁より約 $1 \mathrm{~mm} の$ 所に切線を入れ目標とした.この実験の結果犬にてる人 間と同㥆な変化が括こることが認められたので，実験動 物に大を用いて大過なき結果をえられるものと考えた。

2. 実验方法

予備実験の結果に基づき，実験動物沉は犬を用いたが 生長につれての变化を明瞭に知るためになるべく幼犬を 使用した，予め直接呢頭鏡下に喉頭に病変・異常のない ことを磪めたのち，頭部をいずれかの方向に迴転，ある いは傾斜した状態でギブス固定を行つた，その生存期間 は最長2ヶ月, 最短 2 日であった。

3. 実験結果

A. 左廻転頭位

幼犬の頭部を左迴転頭位にギブスで固定し（第1図） 2 ケ月間生存させ, 断頭固定し, その碩頭を摘出し以下 述べる観察を行つた。

摘出喉頭の外観は（第 2 图）左一廹転する外力のため に，甲状軟骨は左方八擝動されて変形してをり，左葉が くば、主な外力が左前方より加わつたことが判る、搌

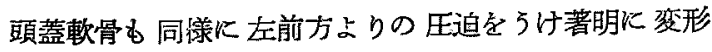
し，甲状軟骨唤頭蓋間隚は左が狭く右が広くなつてい る.更に梨状陷凹山左側狭く梁く，右側では広く浅い。

喉頭蓋の先端と啒頭上り下方，気管輪の正中点を結ふ 中点の軌跡は，正常のそれに較べ著しく屈曲し，後方よ り天ると S 字状の棥曲が認められる。

また啒頭前庭の形は（第 3 図）全体として，左壁は後

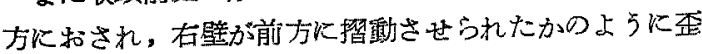

んでをり，前部の前連合部が左前方に引かれ，後部後連 合は右後方より压迫されたかのように左後方におしつけ られ，全体として右前方上り左後方に斜になり，しか子 左側が浅くくぼんた逆「く」の字型を呈している。

脆頭前庭上り内景をみると，左仮声带は突出し，左声 帯は幅狭くみ充，その辺縁の水平位は右声帯のそれに較 べ高く，声門下腔粘膜の左側は内方に突出している. 逆 飞右声帯は幅広く, 水平位が低く, 声門下腔粘膜の右側 は見ることが困難である。

摘出した㗋頭を活ざその中央で前頭断し，その前半部 学後方よりみると（第 4 図），直すに気付くことは，声 帯・仮声帯・モルガニ一氏洞の著明な变形である。

左側（廹転側）では，声帯が厚く，声带上面の水平位 は高く，声門下腔粘膜は膨出し，声带边緣の稜線は上外 側方にあり，辺縁は上外方にまくれ出している.モルガ 二一氏洞は上・下・側方の 3 万向上り王排された如く狭 くなり，洞粘膜の一部は、翻転し著明な晚壁の形成をみ る.

これに反し右側では，声带は薄く，その辺縁の稜楾は 内側下方汇あつて，恰も声門下腔にひき边まれているよ うな所見を呈する。モルガニー氏洞は著しく拡大され， その底面，即ち声带上面は外側下方に向つて著しく低下 している.また声門下腔粘膜は左方に輍べむしろ宿凹し ている:

更にこの断面において，喉頭内腔側壁と甲状軟骨との 間は，左側で薄く，右側であつい：ま同榚に甲状軟骨 々輪状軟骨間の隔りむ右側で広くなつている。

これらの関保を計測図示したのが第5 図でちる.これ らの計測基準を示すと、もル は声帯㲽縁棱線と，モルガニ一氏洞上緣の辺縁掕線の距 離で示した。䐅頭内腔側壁と甲状軟骨間 $\left(a, a^{\prime}\right)$ は，モ ルガニ一区洞の最側方点よりの水平線が甲状軟骨内側に 達する距離で示した。両側声帯の厚さ (c， c’) は，各声 带辺緑棱線より下方声帯下腔粘膜上に $3 \mathrm{~mm}$ の点をと りまた一方，側方声帯上面化 $3 \mathrm{~mm}$ の点をとり，そ の結合線の長さをとることにした、モルガニ一氏洞，輪 状軟骨間 $\left(d, d^{\prime}\right)$ ，甲状軟骨，輸状軟骨間 $\left(e, e^{\prime}\right)$ は各 そその最短距離をとつた。

前頭断した㜊頭の後半部を前方よりみると（第6図）， 前半部の所見とはや〉暴り，右側モルガ二一氏洞は後端 が押された如く左側より浅くなつている。声带辺縁泣前 半部とは逆に，右声带辺縁の水平位の上算がみられる。

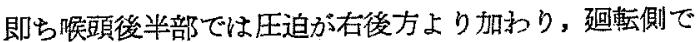


ある左声带は, 前方腱樣部は上年するが、後方では反対 側右声带の軟骨部が上算する結果を示している.

な敃第6図には下坊気管輪断端の後面がみ党るが，そ の気管輸軟骨の後縁は重量し, 左側が気管腔内側に出て いる. 堠頭に加えられた剪断力に対して，最る抵抗の弱 い気管膜様部が押潰されたことを示してをり，また力学 的に，管状弾性体に剪断力か゚加えられたとき，その弾性 が均一でないと最す弱、所に応力が集中することが知ら れてをり，しかも一度変形が特こると, 応力はこの変形 をすすます助成するように作用するものとされている。 そのようなことから，この場合の応力は気管後面以，し かも在後方より加わったと考えられる：

か之して左廻転頭位に固定された犬堠頭は，右後方亡 左前方の 2 方向より押潰されるよ 5 な力 5 け，変形し たことが証明される。

\section{B. 左㑯斜幁位}

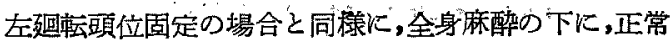
知頭を有する大の頭頸部を左傾斜頭位にギブスで固定し (第 7 凶)，1 ケ月後断頭固定し，喉頭を摘出し検查した.

摘出喉頭を後方よりみると（第8図），舌は右方に曲 り,舌根は右側幅広く、左側は狭く中央におされこの ため堠頭蓋先端は左側咽頭測壁に近づいている・下方で は梨状陷凹は左側で広く，右は狭く潹い，また気管膜様 部は，第II - III－IV気管輪の高さで上下のそれよりも広 がつている.しかし左廻転頭位固定の時にみられた S 字 状の正中線榀曲屺られない。

舌骨をつけたま〉の摘出喉頭を上方からみると（第9 図)，舌骨は左前方から圧迫されて右に倒れた梯形を示 し, 従つて右辺の傾斜度は左辺の乞れよりも小さく，直 立した形をしている。喉頭蓋も庆前方が圧抵されて，在 に較べて平坦である．往つて甲状軟骨喉頭鎾間の広さは 主右大差ない.

堠頭蓋，甲状軟骨の閔係は甲状軟骨左上角は右に押さ れ，右側も亦左方に転位しいる。このため㬋頭蓋との距 離は大で短く，右は長い，喉頭蓋緑より披裂喉頭蓋酦壁 にかけて, 左側は広く側下方に下り, 右は高く中央に䗆 されている。

犊頭入口部の前後軸は前ちでは左に曲り, 後方では右 に偏つている.その後端に打ける所見として，左披裂軟 骨は低下し且つ前方に偏倚し, 右披裂軟骨は高举し後方 にある・声帯突起も亦左側が前方にずれて平滑であつ て，右側は媵方に突出している。

後上方より堠頭盖をみると（第10図），第8図の如く
その辺緑は二等辺三角形を描かす，左辺が長く左側わ，昼 突起は左方に伸び，左前方上り押溃されたようになり， 左底突起は低く後方に，右底突起は高く前方にある．底 突起と咲頭蓋側縁のなす角は左側では鈍角であり右側で は鋭角をなしている。

第正気管輪の高さで下方組織をとりのぞきこへか.ら 上方を是上げると（第11 図），気管の形は走み，右前方 が膨出し，左前面は扁平である. 前方よりみてる右側が 膨隆している、しか子気管輪は気管縦軸导中心として逆 時計方向に廻転变位している。このことは気管が左前方 より圧迫されて坐じた歪と考えられる。

声門下腔に向 5 気管粘膜の傾斜は左側は緩かであり右 側では急峻である。

摘出堠頭を声带前後径の略中点て前頭断し，その断面 を観察すると，後半部では（第12図）声帯の位置は左 側が低く右側では高い. 声門下腔粘膜の声带に移行する 突出部も左側が低く強く突出してをり，右側では高く突 出度も弱い，そのなす角度も右は䋸く左が急でする。

輪状軟骨と甲状軟骨との関係は，右側では甲状軟骨の 内貸に輪状軟骨が上方にくい込んでをり，左側てはこの 二軟骨は互に嗆い込んで和らず，さしろ引き離されよ5 とする傾向がある.

仮声帯の位置も右側は高く左側は低い.モルガニ一氏 洞はその底面, 声带上面は外側に翻転し, 洞上壁より側 壁にかけて大きな粘膜触壁爻形成し全体として右側が大 である。

これらのことは，喉頭内景の左側壁全体が輪状軟营を 含んだまつ下方にずれ，逆に右側壁が全体として上方に ずれたような傾向を示している。

更に㬋頭の前半部（第13图）を双て。これと全く 同様である.輪状軟骨・声帯・仮声帯・モルガ二一氏洞 等が一体となり，右側は上うに左側は下方に移動してい る. 従つて, 輪状軟骨の断面は甲状軟骨断面に対して, 右測では上方に左側ではより下方に位している。

個々にみれば，声帯は全体として右側が高く，左側が 低い. 声带の愿さも右側に比し左側方浡い.声帯縁は右 側では鋭角的で高いのに，左側では鏠であつて低い，モ ルガニ一氏洞は右側では哚く広く，左側では浅く狭くな つている。

この左傾斜頭位に固定した場合, その喉頭殊见声带に 及ばす影響は前述の如く、傾斜側では全体が下方に拥し 下け゚られ，声带は厚さを孪すと同時汇区対側に較べ低位 となりまた上方より下方に问 5 辺縁粘膜の摺動を認如 る. 
反対側ではこれと遗に 全体として上方に 押し上げら れ，声帯は薄くなり，しかるその水平位は高くなり，辺 縁粘膜は下方より上方に向い望動する。

\section{III. 総括及び考按}

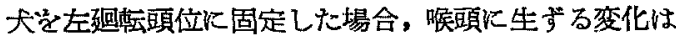
上記の如くであり，その声帯辺縁の替動，声帯水平位の 上輩，下降恃全く人間において臨床的に観察し推測され を变化と一致する。

いま啹頭・気管を一つの管状弾性体と考え。これを直 埾 $3 \mathrm{~cm}$, 長さ $10 \mathrm{~cm}$, 厚さ $3 \mathrm{~mm}$ のゴム管で代用しそ の正中線の上下に切線を入れ，その部を後として右辺を 内方汇重ねながら上端は前壁そ左へ，下端は後壁を左へ 揄ると(第 14 図), 各部括ける応力の方向と変化の模

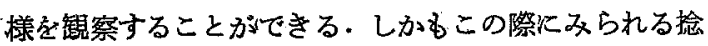
れ汇より生じた稜線の方向は, 摘出喉頭を後方よりみた 場合の正中線の方向とかなりよく一致しているようにみ 兑，試みに両者の写真を重ね合わすと（第 15 図）その 稜線はよく合致することを示している。

このように偋頭をその弾性率が均一の管状弹性体と考 一ある力が加党られたとき，いかなる変化が管 状体に生するか在物理学的沉考察する。

弾性体の底面に平行な方向に力が加えられたとき，単 位面積作用する剪断力を $\mathrm{p}$, 剛性率を $\mathrm{n}$, 歪の角を $\phi$ とすれば（第16図） $\mathrm{p}=\phi \mathrm{n}$ なる式が成立する.

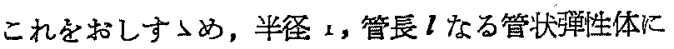
剪断力が加えられた場合，その各部分は上記の如き立方 体をしている之考兄られ，円筒の中心より $\mathrm{r}$ の距離に ある点（円筒の表面）には $\phi$ なる在をうけることにな

\section{第 16 図}

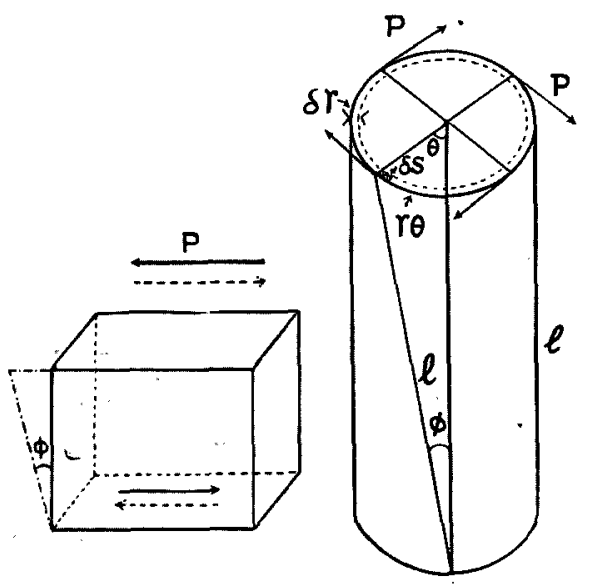

る逆们筒が中なる歪をうけるにはどれ丈の力が必要 であるかをみると，円筒の肉厚 $\delta \mathrm{r} か ゙$ 小ならば $\mathrm{r}+\delta \mathrm{r} の$

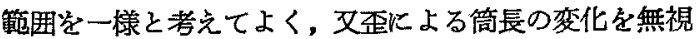
しちるので,こつに作用する力 $\delta \mathrm{p} は \phi=\frac{\mathrm{r} \theta}{l}$ であるか ら $\partial \mathrm{p}=\delta \mathrm{s} \times \phi \mathrm{n}=\frac{\mathrm{r} \theta}{l} \mathrm{n} \delta \mathrm{s}$ となる非心軸作用する力 の能率は rp であり，全体を揄る力の能率は $\delta \mathrm{C}=\delta \mathrm{sp}$ となる。

一方環状の 斜線部の一小部分の 面積は， $\delta \mathrm{s}=2 \pi \mathrm{r} \bullet \hat{c} \mathrm{r}$ であるから， $\delta \mathrm{c}=\mathrm{r} \cdot-\frac{\mathrm{r} \theta}{l} \cdot \mathrm{n} 2 \pi \mathrm{r} \delta \mathrm{r}=\frac{2 \pi \theta \mathrm{r}^{\mathrm{s}}}{l} \mathrm{n} \delta \mathrm{r}$ とな る。肉厚を( $\left.R_{1}-R_{2}\right)$ で示せば，この円筒に作用する力は $\int_{\mathrm{R}_{2}}^{\mathrm{R}_{1}} \frac{2 \tau \theta \mathrm{r}^{3}}{l} \mathrm{n}$ ・or で示され,これは $\frac{2 \pi \pi^{\theta} \pi}{l} \int_{\mathrm{R}_{2}}^{\mathrm{R}_{1}} \mathrm{r}^{3} \delta \mathrm{r}=$ $\frac{\pi \theta \mathrm{n}\left(\mathrm{R}_{1}^{4}-\mathrm{R}_{2}^{4}\right)}{2 l}$ となり, 力は $\mathrm{C}=\frac{\pi \theta \mathrm{n}\left(\mathrm{R}_{\mathrm{i}}^{4}-\mathrm{R}_{2}^{4}\right)}{2 l}$ となる。

このことは同筒を上からみて，фなる每変化を拉こさ せるのに必要な捻じる力は筒長に反比例し，内・外堡の 半径の 4 乗の差に比例するといえる。

即ち肉が厚い程大なる力が必要なことが判かる。るし 肉厚が薄いものとすれば $R_{1}=R_{2}+t$ とて示され $R_{1}{ }^{4}=$ $\left(R_{2}+\frac{R_{2}+t}{R_{2}}\right)^{4}=R_{2}{ }^{2}\left(1+\frac{t}{R_{2}}\right)^{4}=R_{2}{ }^{4}\left(1+4-\frac{t}{R_{2}} t \cdots \cdots\right)$ $=\mathrm{R}_{2}^{4}+4 \mathrm{R}_{2}{ }^{3} \mathrm{t}+\cdots \cdots \cdots$ となり, $\mathrm{R}_{1}^{4}-\mathrm{R}_{2}^{4}=4 \mathrm{R}_{2}^{3} \mathrm{t}+\cdots \cdots \cdots$ となるために， $\mathrm{C}=\frac{2 \pi \theta \mathrm{nR}^{3} \mathrm{t}}{l}$ と簡単にすることがで き, 力の能率 $\mathrm{C}$ は半径の 3 乗, 弾性率に比例し, 筒長 飞反比例する.

この二式よりして，細く，薄く柔か心椟頭では C は 小さくてすみ，動物実験汇る幼若動物を使用した方が明 瞭な変化を特こしうることが推定される。

前述した事項を再録してみると，左右廻転頭位儿する ことにより呢頭に㧍こる主な变化は，外力は迴転側前上 方より吕方り，搌頭はこのためと迴転側前方と反対側後 方より押潰されるようになる。また院頭・気管は廻転側 にその頭を向ける S 字状のよじれを生ずる.

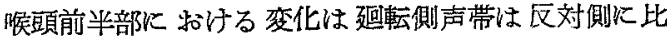
し. 厚さをましその水平位高く，声带辺縁は上外側方以 耺位している.モルガニ一氏洞は廹転側にて上・下・側 方の3方向より压排されて狭小である。

反対側にては，声帯は薄く，水平位は趈転側认較べ低 く，その边縁は内下方に転位し恰も声門下腔にひかれて 
いるような観を呈している・モルガニー氏洞は著しく拨 大している.

これに対し, 後半部ではや」趣を異にし, 迴転側声帯 の辺縁に水平位の低下が就こる.このことは迴転側声帯 の前方腱稼部之，反対側声带の後方軟骨部の上昇が同時 におこると考えられる。

左右傾斜䌿位の㩔頭殊に声帯に及洔す影響は前述の如 く，傾斜側では全体が下方におし下げられたように，声 帯は厚さををしそれと同時江水平位は低下する。

反対側では逆に全体として上柿におし上げられ，声带 は愿さを減じしかもとの水平位は傾斜側より高位とな る.

このことは傾斜惻声帯の水平位の低下と，辺緑粘膜の 上方上り下方に向 万揳動, また反対側声帯の水平位の举 上と辺縁粘膜の下゙方より上方へ向 5 摺動が括こると考兑 られる。

この 2 楎の実験結果をその主要点をとりあげてまとめ ると，第1表のような結果がえられる。これをみると，

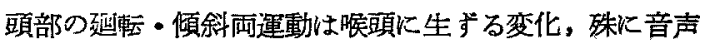
に対する影響の大きい搌頭入口部, 声帯の变化飞特い て，そ派生的変化，量的な大きさ号別にすれば互にそ

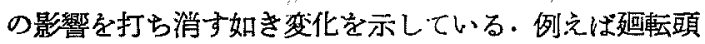

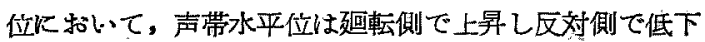
するが，傾斜頭位では傾斜側が 低下し反対側で上景す る.

人生体ではこのような動物実験で行つたような殆んど 純粋な左右廻転頭位あるいは左右傾斜頭位をとることは なく，通常この両者が適宣組合さつた状態であると考え

\section{第 1 表}

\begin{tabular}{|c|c|c|c|c|}
\hline 部位 頭位 & 㝓 枟 & 䫑 位 & 傾 斜 & 頭 位 \\
\hline & 名国枟㑡 & 区対 側 & 傾斜 側 & 反 対 側 \\
\hline 声非水平位 & 上晶 & 低 下 & 低 & 上曻 \\
\hline $\begin{array}{l}\text { 声帶辺綠の } \\
\text { 粘膜 䅛動 }\end{array}$ & 下 $\rightarrow$ 上 & 上 $\rightarrow$ 下 & 上 $\rightarrow$ 下 & 下 $\rightarrow$ 上 \\
\hline 声門下腔 & 佌 出 & 陷凹 & 膨 & 陷 凹 \\
\hline $\begin{array}{l}\text { モルガ }=\text { 润 } \\
\text { 氏 }\end{array}$ & 涨 & 広 & 狄 & 広 \\
\hline 梨子状営 & 深 & 広 浅 & 広 & 猕＼cjkstart深 \\
\hline 喉頭入口部 & \multicolumn{2}{|c|}{ 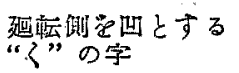 } & \multicolumn{2}{|c|}{$\begin{array}{l}\text { 前方は傾斜側に，後 } \\
\text { 方は反对側による }\end{array}$} \\
\hline 喉頭・気聟 & \multicolumn{2}{|c|}{$\begin{array}{l}\text { 反対例总上とした } \\
\text { S字状に掕孔る }\end{array}$} & \multicolumn{2}{|c|}{$\begin{array}{l}\text { 屈側は下方に拥下 } \\
\text { げしれ反对側さ上 } \\
\text { 方に上る }\end{array}$} \\
\hline
\end{tabular}

られる.この点 2 種の実験結果が互に相反する如き変化 をひき怙こしていることは誠興味あることである。

以上の如き結論について再考するに，本実験は頸部外 側よりギブス固定を行つて観察したるのであるから、こ れが人間に特ける左右迴転，傾斜頭位によつておこる变 化と同傔であるか否かの点である.この点に関し，ある いはこの 2 方向の頭位でなく中間頭位をとつた場合の侯 頭はいかなる变化を扣こすかということをる合め，更炕 胸鎖乳突管の一側縫縮，切断，あるいは銀線による頭部 と助骨との毫引等の方法をとり綕果を追求せんとした が,これらの方法では，長時日の固定が不可能であつた こと，あるいは固定の方法によっては頭頸部を，固定し たとい党ない位の自由さるるつていること等によりぞ れによる明睹な变化をみとめることができなかつた。 そ のためにこつに報告したような外部よりの固定と，頸 部内側より行つた固定の差違，更にはそれらと生体の任 意の頭位の場合と前者との関連性，不同性を追求しきれ なかったことは遺感である。

さて翻つてこの頭位の变換により，頸部の屈曲や㨝れ によって生ずる啹頭内景殊に声带の䣏変については、交 献上これを求めることができずこのことは前論文であ言 及した：在来言われている声帯の変化は，発声時の声帯 運動及びその運動形式についで゙あり，僅少のむいに臨 床的事実炕基づいて声帯水平位差の变化が推諭的汇述一 られているにすぎない

かつる水平位差の变化を指摘している論交はその多く が一側反回神経麻痺症例についてがあり，ある䫄位をと ると音声が改善されることにより麻痺側声带の緊張がま

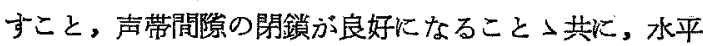
位莖の匡正があううと述い゙ている。乙かし水平位差が匡 正されたと断言している訳でななく，また麻痺側の水平 位が低下しているともことわっていない。

前論交 ${ }^{6)}$ でもふれたが，これらの論交の5ち，著者 の動物実験の結果とよく適合する例が報告されているの は当然とはい党興味をひかれる. 即ち R. Hoffmann のいう下顎を麻疩側の肩へつけるような運動は，頭を患 側一迴転することであり，実駼結果よりこれは麻疩側声 带の水平位の挙上を括こすと知られ，なた H. Sternの 健側に頭部を屈することは，患側声帯の水平位る举上す ることであるとして括り，共に麻盘側声带の水平位を上 げることであることを知つた。

以上の如く交献上体問題に関する記載が少いのであ るが，著者の行つた臨床的観察や実験結果からすれば， 
鳥山論文附図 (I)

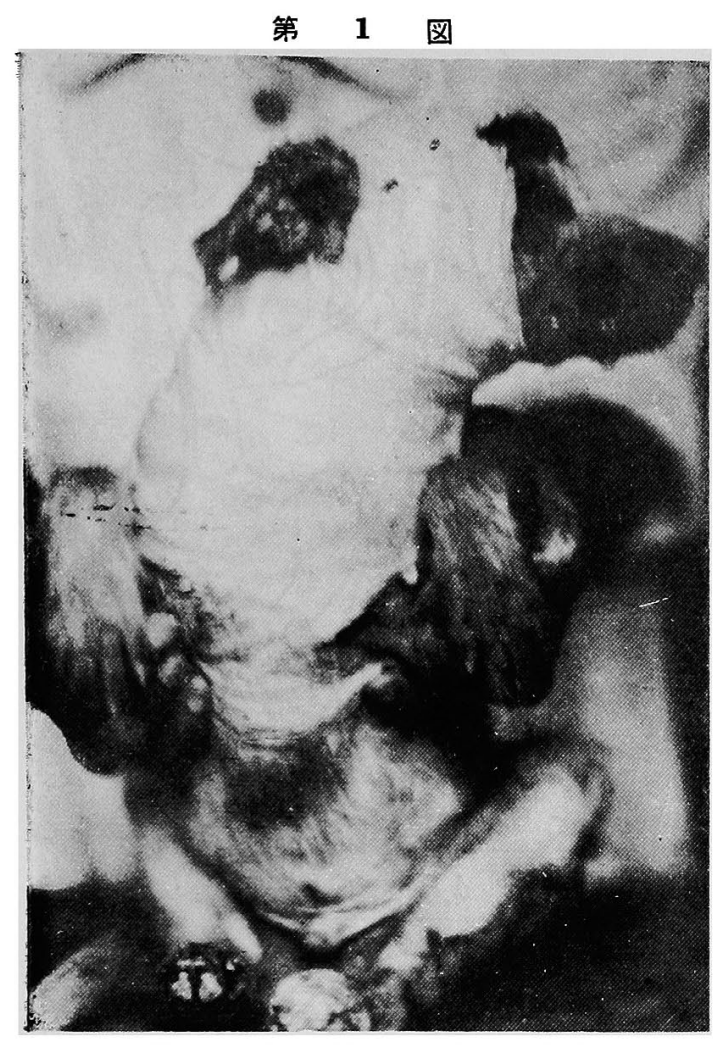

纤犬の左趈転頭位ギブス固定した所

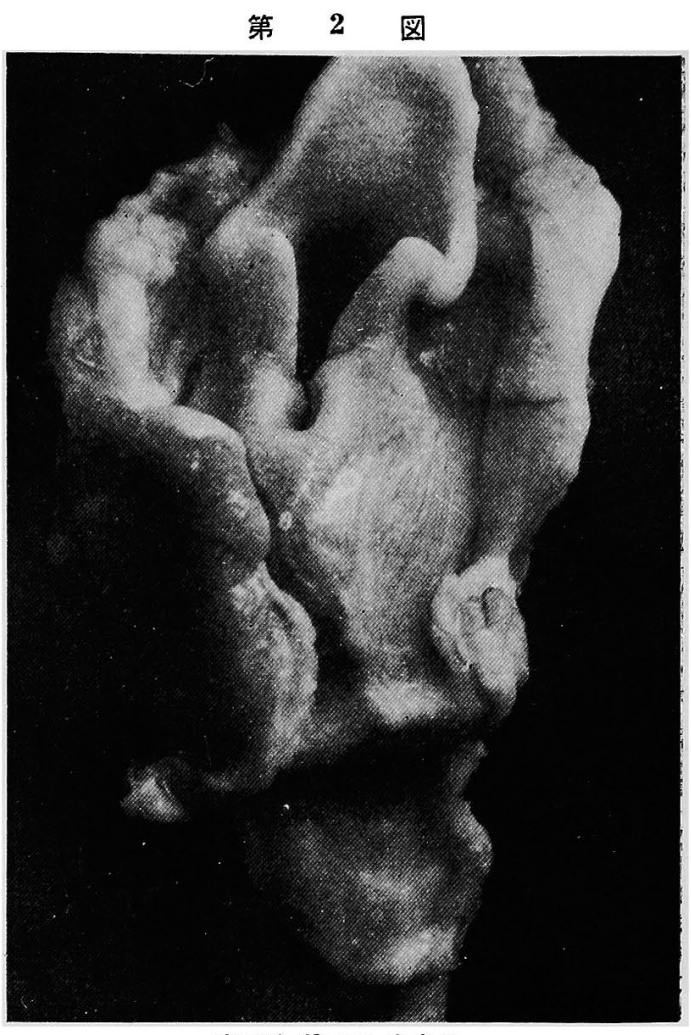

啹頭花後方よりみる

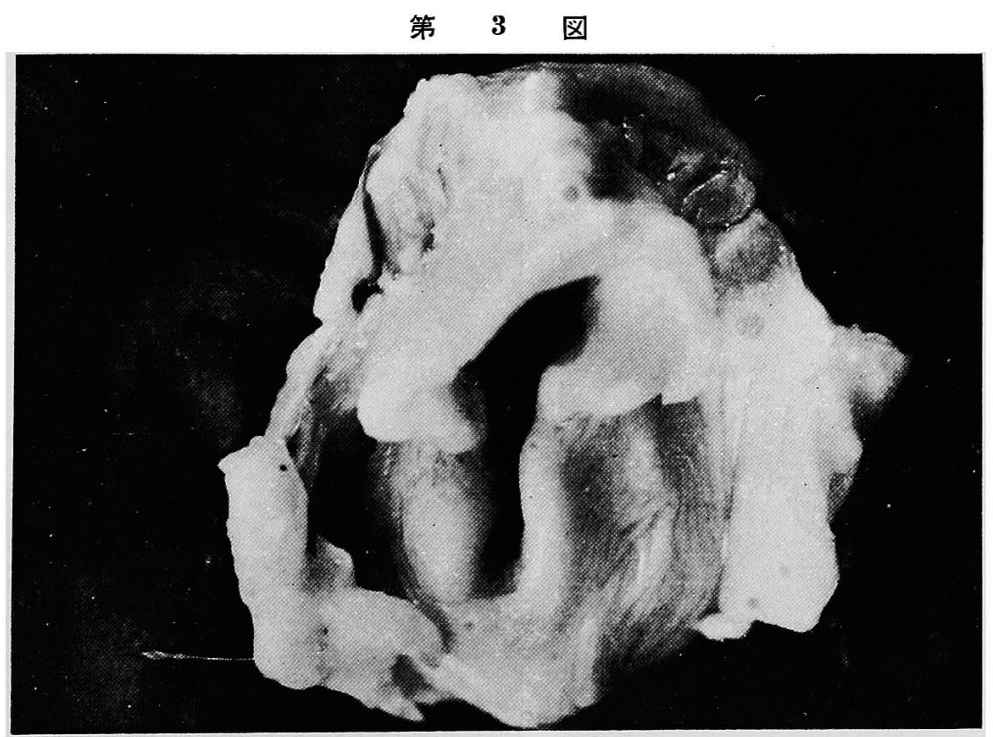

喉頭它上方より 
鳥山論交附図 (11)

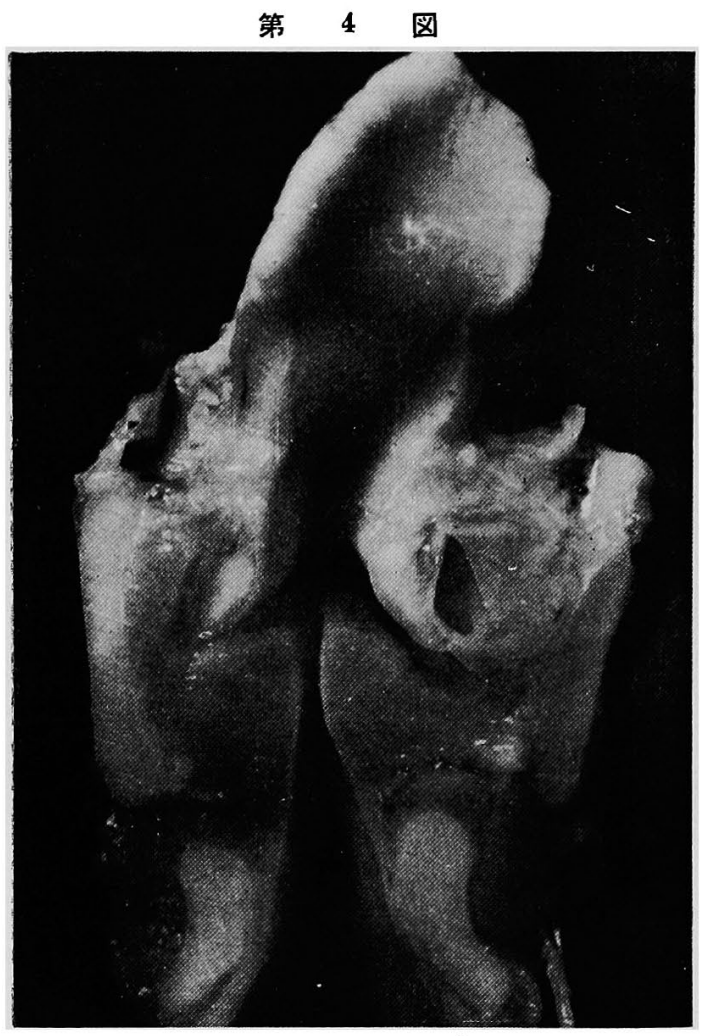

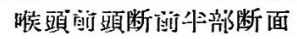

第 6 図

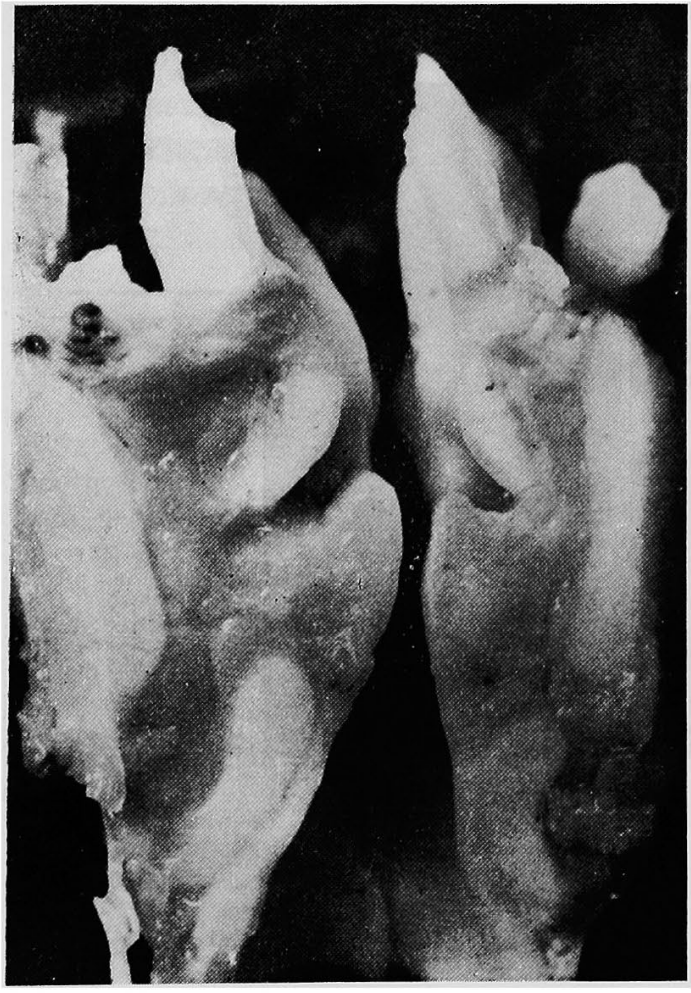

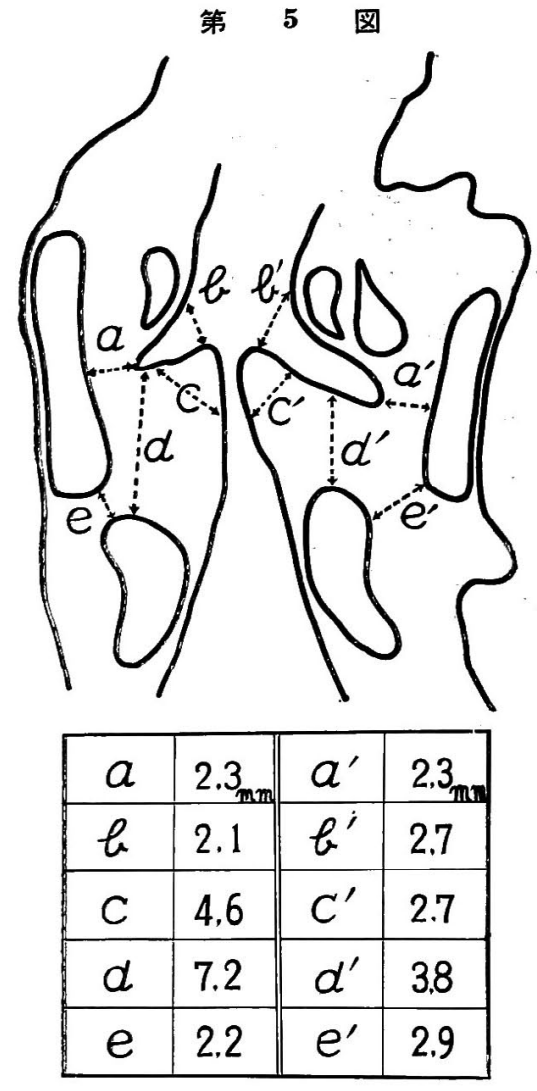

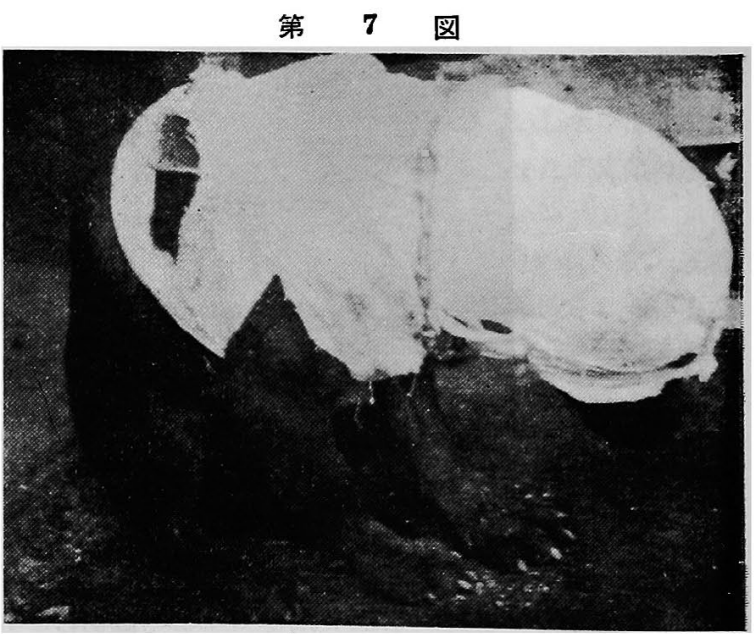

左他斜蹎位にギブス固定 


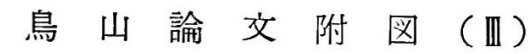

第 8 図
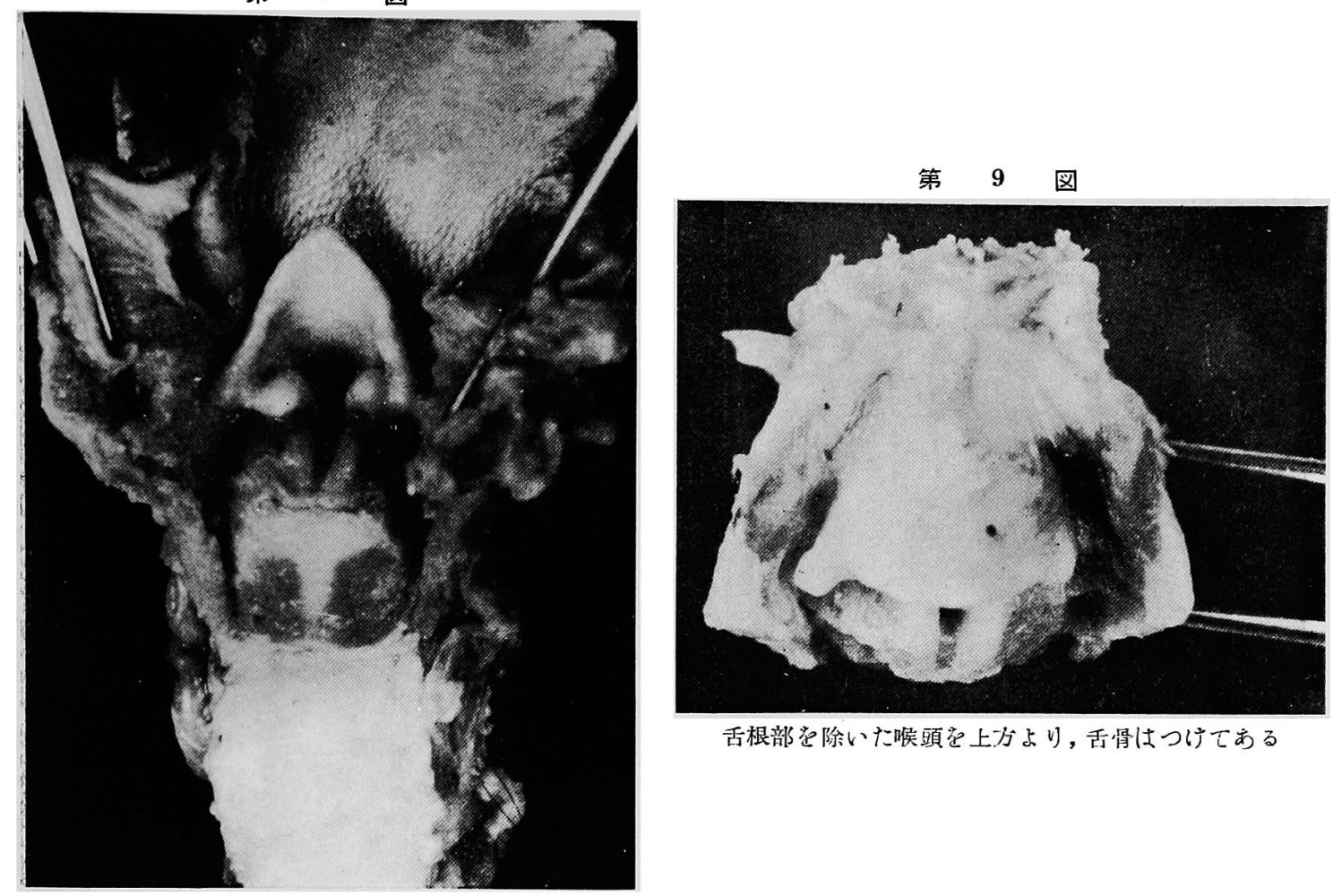

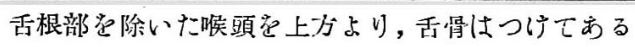

舌根をつけた喉頭を後方上り

第 10 図
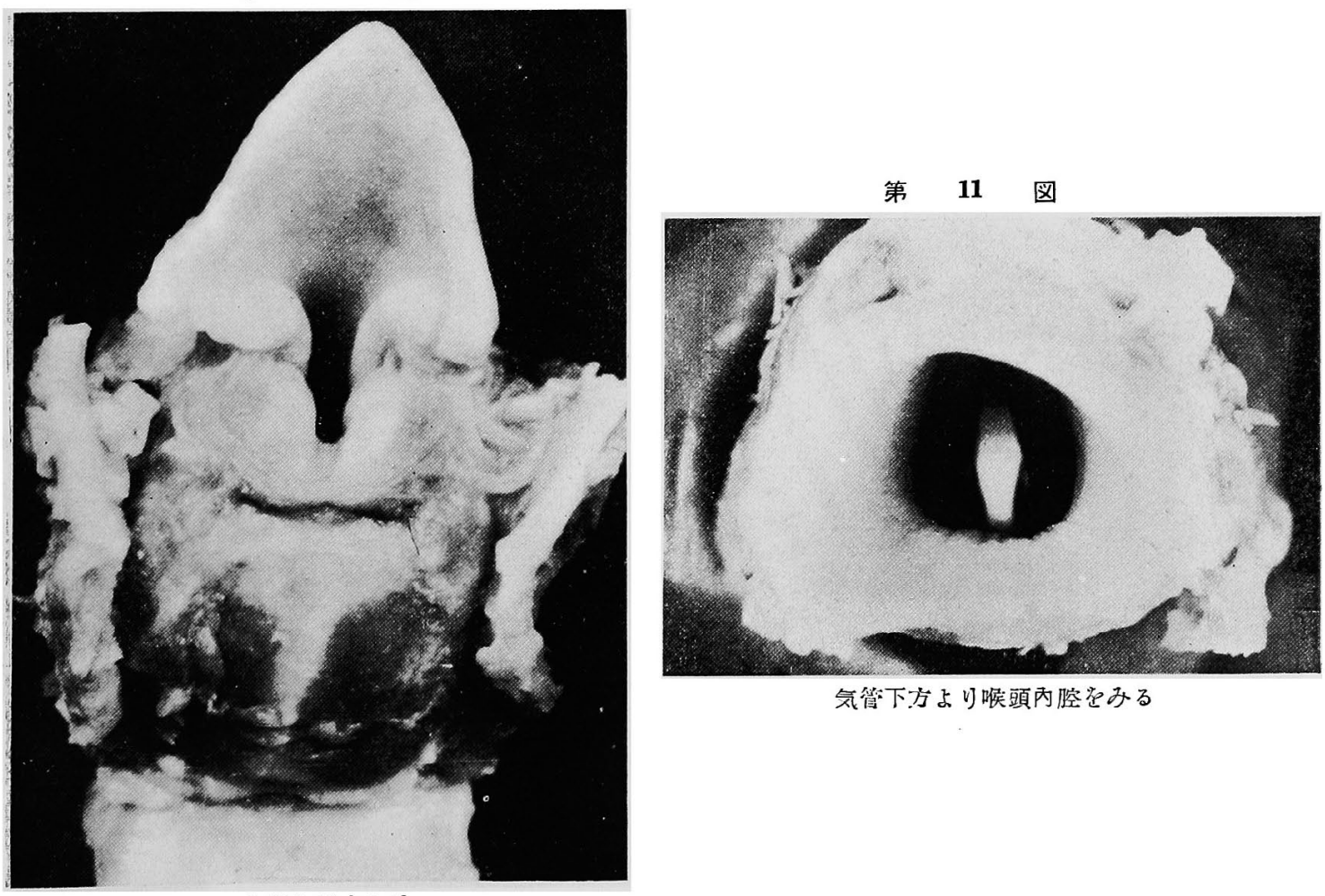

気管下方よ喉頭內腔をみる

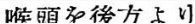


鳥山論交附図 (N)

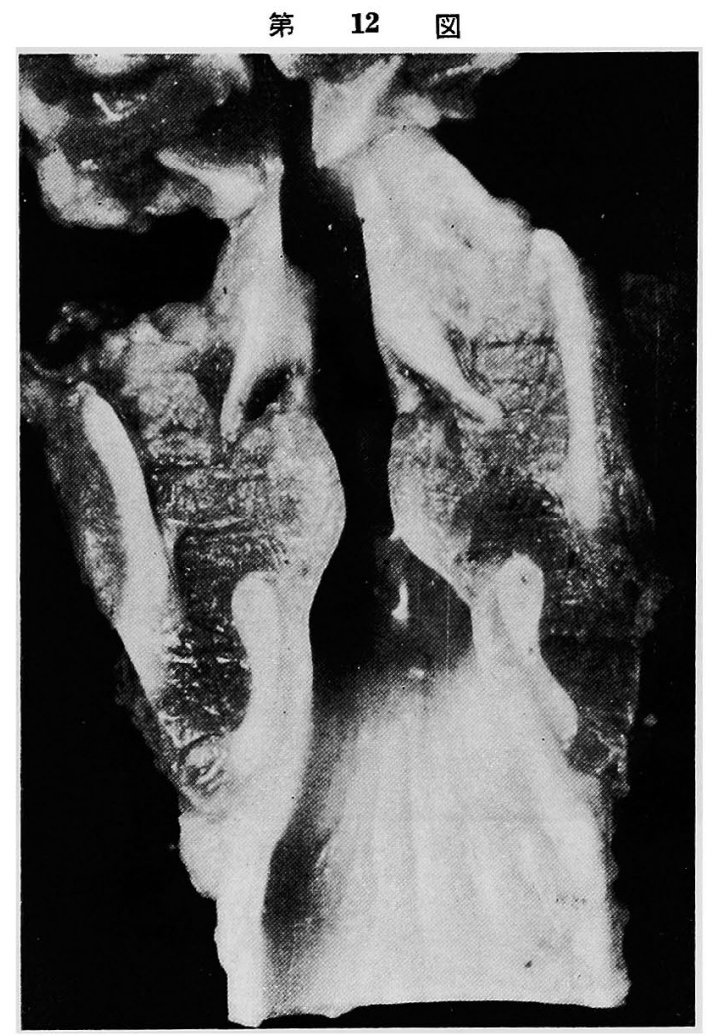

喉頭前頭断後牛部断面

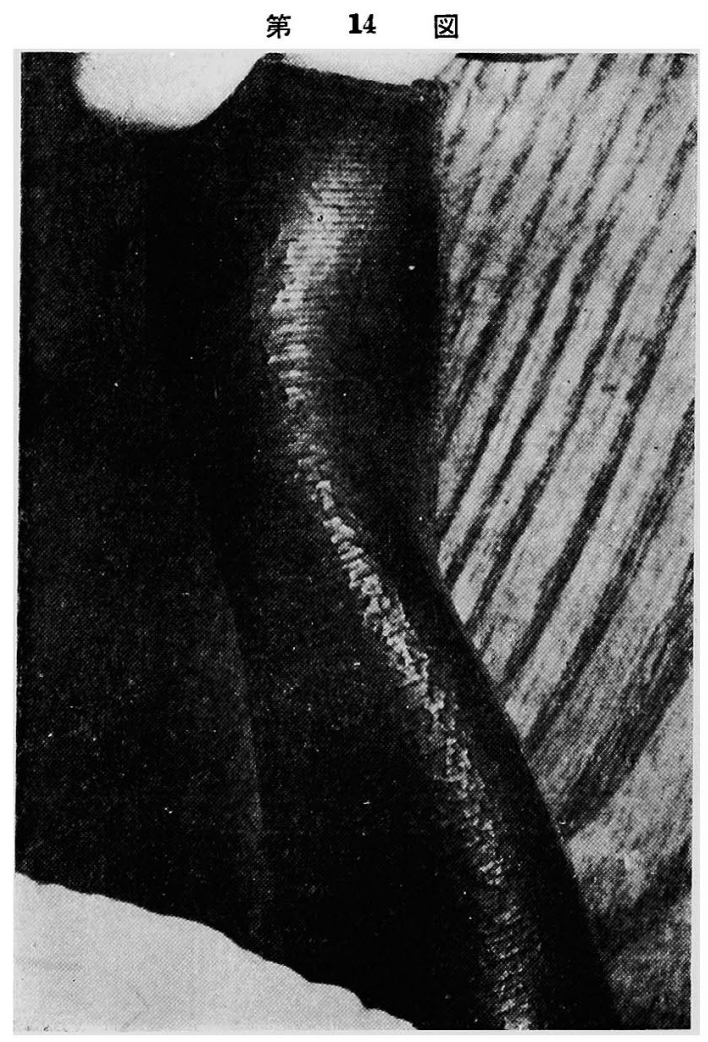

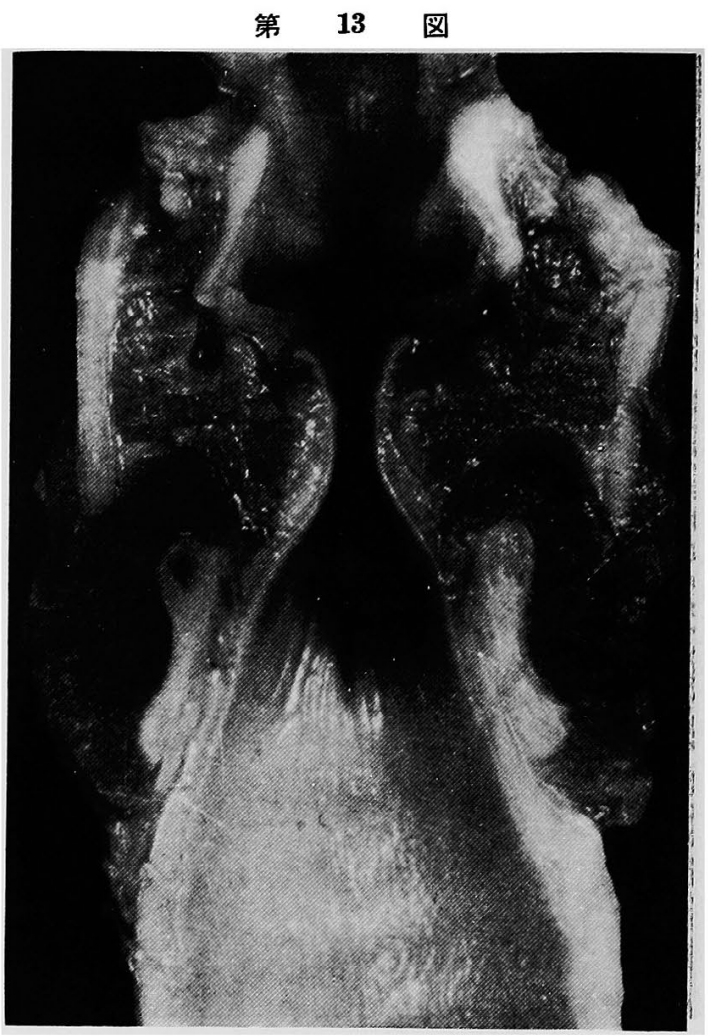

喉頭前頭断し前牛部断面

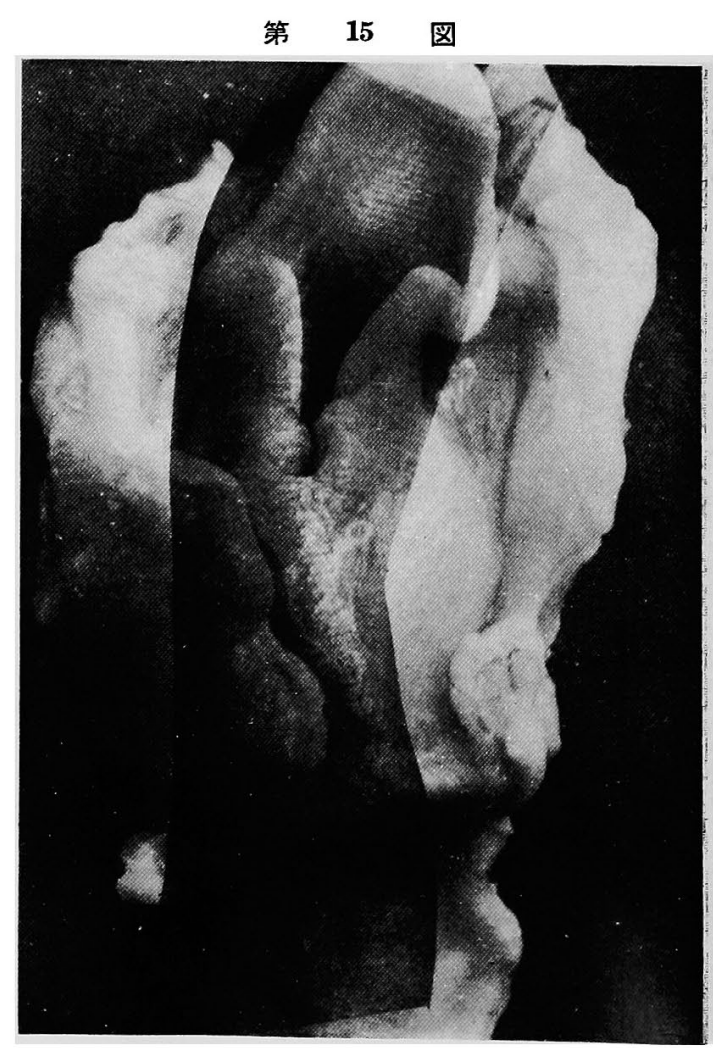


頭部の左右廻転，あるいは左右傾斜が胙頭に前記のよ5 な変化をおこすことが推定され，それが音声に及ぼす影 帮は大なるすのといつて過言ではない、またこの一連の 動物実験の成漬は，左右廻転頭位また左右傾斜頭位等の

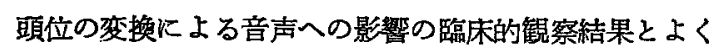
一致し，その真実性を嫨書する結果となつてをり，見方 を変えれば正面位発声に比して，他の頭位で発声するこ とが普声生理学的にみて不適当であるというがとができ ろ.

\section{IV. 結 語}

臨床的に頭位の变换が 喉頭・音声に 及住す变化を知 り，頭位の变换が喉頭にいかなる变化を葱起するかを検 討するために，動物実験を行つた。

実験動物には奻若犬を用い左迴転頭位，または左傾斜 頭位にギブス固定を行い，一定期間生存せしぬた後断頭 固定し，喉頭を摘出し検索し，下記の新知見を得た。

迴転頭位の埸合には，迴転側において声帯水平位は上 昇し声帯辺縁粘膜は下方より上方へ摺動するが、，立対側 では声帯水平位は低下し、声带辺緑粘膜は上方より下方 に摺動する。

傾斜頭位の場合は，僓斜側声帯水平位は低下し，反対 側で上昇し，声帯辺緣粘膜は傾斜側では上方より下方 へ，反対側では下方より上方へ摺動する。

以上の如き主要所見は, 種々の頭位にて発声する場合 の臨床的所見と合致すると共に, 頭位の变換による発声 上の問題一一正面位発声が他の頭位にての発声よりる自 然であること一爻改めて認識した。

文献

1) Arnold, G.E.: Mschr. Ohrenheilk. 75; 407, 1941. 2) Arnold, G.E.: Die traum. u. konst. Stör. d. Stimme u. Sprach. $1948 . \quad 3)$ Briefkasten:

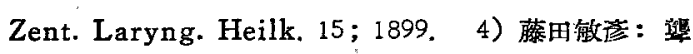
鲐教育，18；12, 昭 7. 5) 藤田矮一, 鳥山寧二：日 耳悬, 乔 32 揭载予定. 6) Grossmann, G.: Msch. Ohrenheilk. $34 ; 123,1916 . \quad$ 7) Hoffmann, R.:
Zent. Laryng. 7 ; 1915. 8) Katzenstein. F.: Zent. Hals.-usw. 3; 438, 1922. 9) Luchsinger, R.; Schweiz. Med. Wschr. 66;760, 1936. 10) Luchsinger, R.: Pract. Oto-Rhino-Laryng. 5; 270, 1943. 11) Luchsinger, R.: Zent. Hals-usw. Heilk. 50; 107, 1944. 12) Luchsinger, R. \& Arnorld, G.E.: Stimm-und Sprach-heilkunde. $1952 . \quad$ 13) Nadoleczny, M.: Zent. Hals-usw. Heilk. 6; 418, 1923 , 14) Nadoleczny, M.: Arch. Ohr-usw. Heilk. 44 ; 1, 1938. 15) 小川常二：大日耳费，46；1379, 昭 18 。 16) Recker, H.: Arch. Sprach u. Stimmheilk. 2; 215, 1938. 17) Seemann, M.: Mschr. Ohrenheilk. 55; 1621, 1921. 18) Seeamnn, M.: Arch. Laryng. 32; 2, $1929 . \quad 20)$ Seemann, M.: Wien. Med. Wschr. 1923. 21) Seemann, M.: Arch. Laryng. 32; H2, 1941.22$)$ Spiess: Arch. Laryng. 16; H3, 1925. 23) Stern, H.: DenkerKahler Bd. 5; 930, $1929 . \quad$ 24) Stern, H.: Zent. Hals-usw. Heilk. 8；256, 1924.25$)$ 埕田琴次, 藤

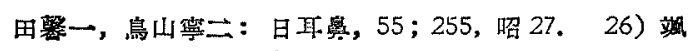

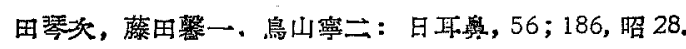

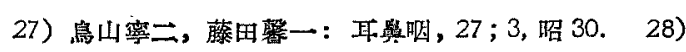
Weleminsky, J.: Zent. Hals-usw. Heilk. 8; 256. 1924.

擱筆するにおたり，本研究の示唆を与えられ

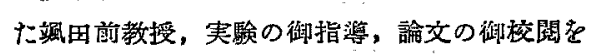
賜わつた切替教授，藤田 (㢣) 蓝版に感謝する。 又東大工学部荒机瞅教授の御教示に感謝する。

(本諭交の要旨は昭和 27 年, 28 年の日本耳悬 昀喉科学全䋓会において発表した).

（原傐到䇺=㸛租 32.10 .22 日） 